\title{
Preface: Legal Reforms and Legal Culture in Japan
}

\author{
Harry N. Scheiber
}

The recent movement for extensive reforms of law in Japan, given impetus both by domestic political pressures and by the perceived imperatives of economic globalization, is a subject of deep interest to students of comparative law. Because of the creation of new legal institutions and adaptation of the civil law system's jurisprudence in the Meiji Restoration, and then the equally comprehensive reforms of the post-World War II Occupation period, the Japanese experience with law reform has had a unique historic configuration. Long recognized, however-and indeed given central importance in scholarship on Japanese law by writers both in the West and in Asia-has been the extraordinary historic persistence in Japan of cultural norms as to law, especially with regard to hierarchy and deference, and to the ideals of consensus and social harmony. Both political and socio-legal structures as well as consensual values famously have shaped-and often blunted or offset-the transformative objectives of newly fashioned formal law Similarly intriguing to students of Japan has been the perduring resiliency of power relationships that define real-life legal ordering (whatever "law in the books" may indicate).

The articles on Japan in this issue of the Journal revisit these issues as they assess the efforts going forward today for law reform there. The authors have updated and revised papers first written for a symposium at Boalt Hall School of Law under auspices of the school's Sho Sato Program in Japanese and U.S. Law. The methodologies represented here vary, as is appropriate given the much-noticed diversity of approaches in the scholarly literature on Japanese law and legal culture. Thus several of the papers undertake socio-legal analysis and stress issues of cultural persistence, governmental process, and norms of legal behavior. Other authors, in discussions of specific legislation and other initiatives for law reform, provide fresh perspectives on the sources of reform pressures and objectives, also placing the reforms in their political contexts. The ever-present issues of conscious adaptation from foreign models of law and legal institutions; of the internal sources-bureaucratic, political, and cultural-of resistance to change; and, not least important, the implications of the extraordinary scope, speed, and potential reach of the reforms taken as a whole, all receive analysis in these studies.

Harry N. Scheiber is the Stefan A. Riesenfeld Professor of Law, University of California, Berkeley; and Director, the Sho Sato Program in Japanese \& U.S. Law, Boalt Hall School of Law. 
As the symposium's co-organizer with Professor Kahei Rokumoto, I would like to express special thanks for their important contributions to the conference at Berkeley to the authors represented here and also to Professors Takao Tanase, Setsuo Miyazawa, Hideki Kanda, Hizakazu Hiroke, Richard Buxbaum, Malcolm Feeley, Lawrence Friedman, Robert Kagan, Arthur Rosett, Edward Rubin, and Frank Upham. 


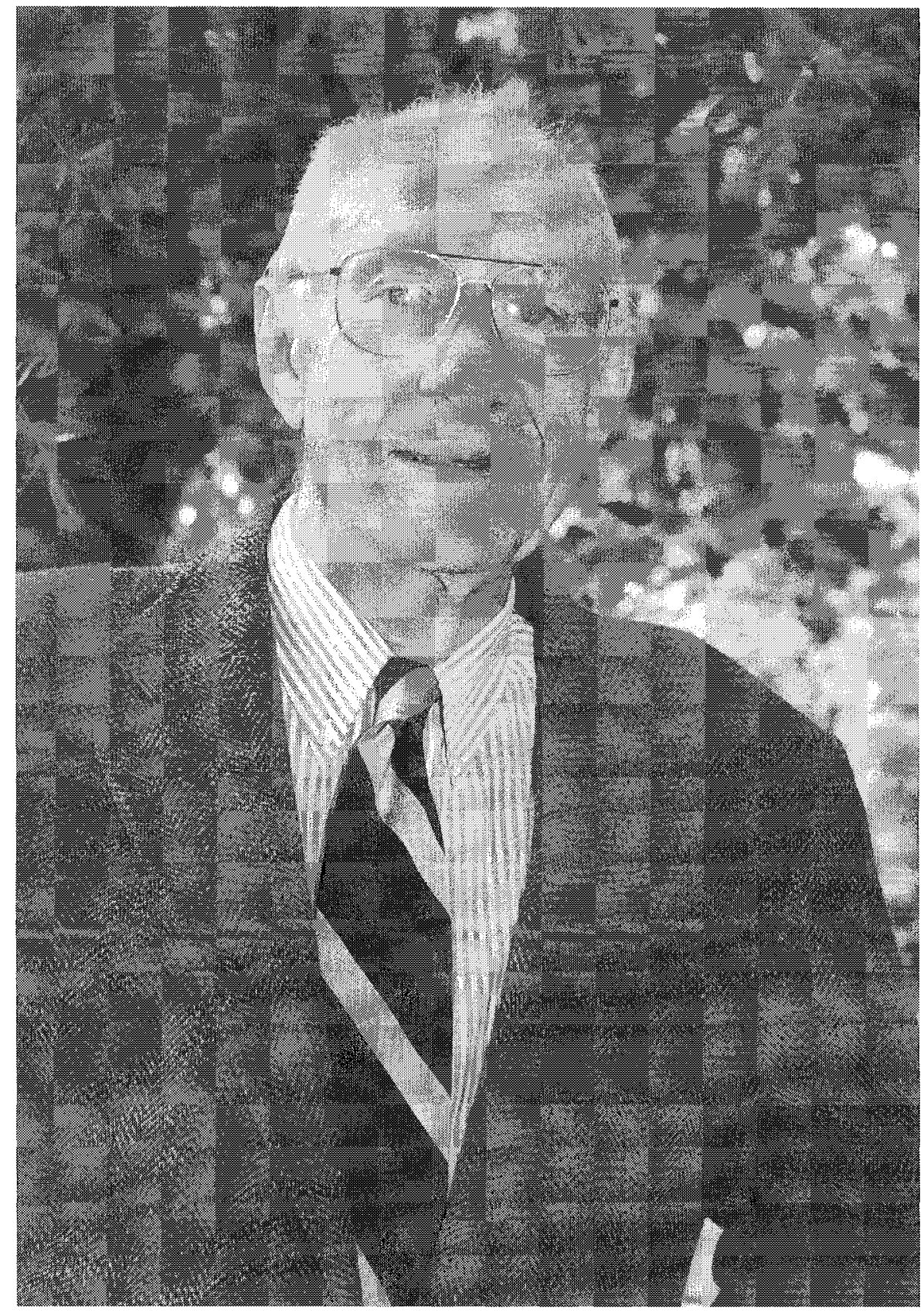

Friedrich KLAus Juenger 1930-2001 
The American Journal of Comparative Law (ISSN 0002-919x)

Published quarterly by The American Society of Comparative Law, Inc. Editorial offices: School of Law (Boalt Hall), University of California, Berkeley, California 94720. Subscription $\$ 30.00$ per year (domestic), $\$ 32.00$ (foreign). If the subscriber wishes the subscription discontinued at its expiration, notice to that effect should be sent; otherwise it is assumed a continuation is desired. Periodicals postage paid at Berkeley, California and at additional mailing offices.

POSTMASTER: Send address changes to The American Journal of Comparative Law, School of Law (Boalt Hall), University of California, Berkeley, California 94720.

Editorial communication and books for review should be addressed to our office of publication, The American Journal of Comparative Law, School of Law (Boalt Hall), University of California, Berkeley, California 94720. Applications for subscriptions may be sent to the above address, or (subject to usual service charges) to:

B.H. Blackwell, Ltd.: 48-51 Broad Street, Oxford, England

Stetchert-Hafner, Inc.: 16 Rue de Cond'e, Paris, 6e France

A.B. Nordiska Bokhandeln: Drottninggatan 7-9, Stockholm, Sweden

Maruzen Company, Ltd.: 6 Tori-Nichome Nihonbashi, Tokyo, Japan

For single copies and bound or unbound sets of back issues, inquire of William $\mathbf{S}$. Hein \& Co., 1285 Main Street, Buffalo, New York 14209 USA. For current and backfile volumes in microfilm form inquire of University Microfilms International, $300 \mathrm{~N}$. Zeeb Road, Ann Arbor, Michigan 48106.

Change of address: Send your change of address to The American Journal of Comparative Law, School of Law (Boalt Hall), University of California, Berkeley, California 94720, at least 30 days before the date of issue with which it is to take effect. The Post Office will not forward copies unless you provide extra postage. Duplicate copies will not be sent. 